\title{
HUBUNGAN KADAR TUMOR NECROSIS FACTOR - $\alpha$ DENGAN DENSITAS PLASMODIUM PADA PENDERITA MALARIA
}

\author{
${ }^{1}$ Maria A. Roinwowan \\ ${ }^{2}$ Janno B. B. Bernadus \\ ${ }^{2}$ Angle M. H. Sorisi
}

\author{
${ }^{1}$ Kandidat skripsi Fakultas Kedokteran Universitas Sam Ratulangi Manado \\ ${ }^{2}$ Bagian Parasitologi Klinik Fakultas Kedokteran Universitas Sam Ratulangi Manado
}

\begin{abstract}
Malaria is a parasitic infection that attacks the erythrocytes. This disease remains a global health problem, especially in developing countries in the tropics and subtropics. Symptomatic malaria infection include fever, chills, anemia and splenomegaly. Malaria infection can progress without any complications but can also develop systemic complications known as severe malaria. The cause of malaria is plasmodium infection, Plasmodium in humans infected erythrocytes (red blood cells) and asexual breeding experience in liver tissue and erythrocytes. In this research, the microscopic examination of blood samples for counting malaria parasites in the blood and then measured the levels of TNF- $\alpha$ by ELISA. This analytical study using 40 samples taken by simple random sampling. The results showed that there is a significant relationship between the amount of TNF- $\alpha$ levels plasmodium with. Conclusions: There were significant correlation between the levels of TNF- $\alpha$ with a density of plasmodium malaria in blood samples.
\end{abstract}

Keywords: Malaria, TNF- $\alpha$, ELISA, plasmodium

\begin{abstract}
Abstrak: Malaria adalah penyakit infeksi parasit yang menyerang eritrosit. Penyakit ini masih merupakan masalah kesehatan dunia terutama di negara sedang berkembang pada kawasan tropik dan subtropik. Infeksi malaria memberikan gejala berupa demam, menggigil, anemia dan splenomegali. Infeksi malaria dapat berlangsung tanpa adanya komplikasi namun dapat juga menyebabkan komplikasi sistemik yang dikenal sebagai malaria berat. Penyebab infeksi malaria ialah plasmodium,Plasmodium ini pada manusia menginfeksi eritrosit (sel darah merah) dan mengalami pembiakan aseksual di jaringan hati dan eritrosit. Dalam penelitian ini dilakukan pemeriksaan mikroskopis pada sampel darah penderita malaria untuk menghitung parasit dalam darah dan selanjutnya dilakukan pengukuran kadar TNF- $\alpha$ dengan metode ELISA. Penelitian analisis ini menggunakan 40 sampel yang diambil secara simple random sampling. Hasil penelitian memperlihatkan bahwa terdapat hubungan yang bermakna antara jumlah plasmodium dengan kadar TNF- $\alpha$. Kesimpulan : Didapatkan korelasi yang signifikan antara kadar TNF- $\alpha$ dengan densitas plasmodium pada sampel darah penderita malaria.
\end{abstract}

Kata Kunci : Malaria, TNF- $\alpha$, ELISA, plasmodium

Malaria adalah penyakit infeksi parasit yang disebabkan oleh plasmodium yang menyerang eritrosit dan ditandai dengan ditemukannya bentuk aseksual di dalam darah. Penyakit ini masih merupakan salah satu masalah kesehatan dunia terutama di negara sedang berkembang pada kawasan tropik dan subtropik. Infeksi Malaria tersebar pada lebih dari 100 negara di benua
Afrika, Asia, Amerika (bagian selatan) dan daerah Oceania dan kepulauan Caribia. Lebih dari 1,6 triliun manusia terpapar oleh malaria dengan dugaan morbiditas 200-300 juta dan mortalitas lebih dari 1 juta per tahun. Di Indonesia Timur mulai dari Kalimantan, Sulawesi Tengah sampai ke Utara, Maluku, Irian Jaya dari Lombok sampai Nusa Tenggara timur serta Timor 
timur merupakan daerah endemis malaria dengan Plasmodium Falciparum dan Plasmodium Vivax. ${ }^{1,4}$

Pada infeksi malaria dapat terjadi perubahan reaktif imun yang lambat pada fase akut dan terjadi sepanjang waktu setelah clearance parasit dalam sirkulasi. Respon imun inflamasi memerlukan clearance parasit yang dapat menimbulkan kerusakan jaringan, mengaktifkan fagosit untuk membunuh parasit intraseluler dan ekstraseluler. $^{2}$ TNF memegang peranan penting , diantaranya efek samping ini adalah demam, kekakuan, sakit kepala, myalgia, mual-muntah dan trombositopenia. Sebagai tambahan, level serum TNF sering berkaitan dengan keparahan penyakit. Dari beberapa penelitian dibuktikan bahwa penderita malaria serebral yang meninggal atau dengan komplikasi berat seperti hipoglikemia mempunyai kadar TNF- $\alpha$ yang tinggi. 3,5

\section{METODE PENELITIAN}

Penelitian ini merupakan penelitian analitik laboratorium untuk mengetahui bagaimana hubungan TNF- $\alpha$ dengan densitas Plasmodium pada sampel darah pada penderita malaria. Pengambilan sampel darah di RSUP Prof. DR. R. D Kandou Malalayang dan RS Noongan. Pemeriksaan dilakukan di laboratorium Biomolekuler Parasitologi Fakultas Kedokteran UNSRAT, Malalayang. Sampel dari penelitian ini diambil secara simple random sampling. Jumlah sampel yang diteliti adalah sebanyak 40 sampel. Data yang diperoleh dari penelitian diolah dalam tabulasi dan dilakukan uji statistik dengan menggunakan program SPSS $\mathrm{v} \quad 21$ Uji statistik yang dipakai adalah uji analisis bivariate cara spearman.

\section{HASIL}

Dalam kurun waktu Oktober 2013 sampai Januari 2014 ditemukan 40 kasus malaria melalui simple random sampling yang terdapat di RSUP Prof Kandou dan RS Noongan, didapatkan hasil Berdasarkan jenis kelamin Laki laki sebanyak 21 orang dan Perempuan 19 orang. Pada pasien dengan usia antara 4-12 tahun. Usia 4-6 tahun sebanyak 9 orang, 7- 9 tahun 21 orang, dan 10- 12 tahun 10 orang dengan dua jenis plasmodium yaitu plasmodium falciparum dan plasmodium vivax, plasmodium falciparum pada 27 sampel darah penderita malaria dan Plasmodium vivax pada 13 sampel darah penderita malaria. Pada pemeriksaan Mikroskopik Semi Kuantitatif pada ke 40 sampel penderita malaria didapatkan + (23), ++ (13), +++ (4). Dari seluruh sampel didapatkan perhitungan jumlah parasit dan kadar TNF-- $\alpha$ yang bervariasi. Dengan jumlah plasmodium terendah 560 dan tertinggi 32080, sedangkan kadar TNF terendah 75pg/ml dan tertinggi adalah 305pg/ml.

Tabel 1. Hasil perhitungan Mean dan Median

\begin{tabular}{lcc}
\hline & $\begin{array}{c}\text { Mikro Parasit } \\
\text { Count }\end{array}$ & $\begin{array}{c}\text { Elisa Kadar } \\
\text { Serum TNF } \\
\text { Alfa (pg/ml) }\end{array}$ \\
\hline $\mathbf{n}$ & 40 & 40 \\
Mean & 4839.00 & 155.75 \\
Median & 1100.00 & 142.50 \\
\hline
\end{tabular}

Dari hasil perhitungan pada Statistical Package for Social Science (SPSS), didapatkan nilai rata rata jumlah parasit dari 40 sampel berada pada 4839 dengan kadar serum TNF- $\alpha$ pada 155,7 pg/mlUntuk membuktikan adanya hubungan antara kadar TNF dan jumlah plasmodium maka peneliti menggunakan analisis bivariate spearman rank.

Tabel 2. Hasil analisis korelasi densitas plasmodium dengan kadar TNF

\begin{tabular}{lll}
\hline $\begin{array}{l}\text { Jumlah } \\
\text { plasmodium dan } \\
\text { jumlah TNF }\end{array}$ & $\mathbf{r}$ & 0.361 \\
\hline
\end{tabular}

Pada Tabel terlihat adanya korelasi positif antara Jumlah plasmodium dengan jumlah kadar TNF dengan nilai $\mathrm{p}=0,022$ yang berarti korelasinya bermakna. 
Roinwowan, Bernadus, Sorisi; Hubungan Kadar Tumor Necrosis Factor...

\section{BAHASAN}

Pada malaria, Eritrosit terinfeksi parasit yang pecah sewaktu proses skizogoni mengeluarkan berbagai toksin seperti glycosylphosphatidylinositols (GPI), hemozosin, atau mungkin antigen parasit lain seperti MSP-1, MSP-2, RAP-1. Toksin tersebut akan merangsang makrofag dan limfosit $T$ helper menghasilkan berbagai sitokin proinflamasi, salah satunya TNF- $\alpha{ }^{4}$ TNF- $\alpha$ merupakan sitokin utama pada respons inflamasi akut terhadap bakteri gram negatif dan mikroba lainnya. Infeksi yang berat dapat memicu produksi TNF dalam jumlah yang besar dan menimbulkan reaksi sistemik. Pada kadar rendah , TNF bekerja terhadap leukosit dan endotel, menginduksi inflamasi akut. Pada kadar sedang, berperan dalam inflamasi sistemik. Pada kadar tinggi menimbulkan kelainan patologik syok septik. ${ }^{5}$

Pada penelitian didapatkan jumlah plasmodium dan kadar TNF yang bervariasi, ditemukan juga pasien dengan kadar TNF yang tinggi, namun jumlah plasmodium tidak terlalu tinggi, begitu juga sebaliknya, keberadaaan TLR juga berpengaruh pada keadaan ini, seperti yang sudah tertera pada gambar 5, TLR berperan menginduksi respon imun sel-sel dalam tubuh hingga menyebabkan terjadinya pelepasan sitokin sitokin pro inflamasi, yang salah satunya adalah TNF- $\alpha{ }^{8}$

Hasil analisa statistik menunjukkan terdapat hubungan yang bermakna antara jumlah plasmodium dengan kadar TNF- $\alpha$ $(p=0,02)$. Hal ini sesuai dengan teori bahwa TNF berhubungan parasitemia. Berdasarkan penelitian dari Hemmer CJ,et al Parasitemia berkolerasi dengan kadar darah TNF- $\alpha$, LDH, TAT. ${ }^{6}$ Teori ini terbukti pada penelitian pada anak anak di Gambian dan India yang terinfeksi plasmodium falciparum. level serum TNF- $\alpha$ diperiksa pada pasien malaria tanpa komplikasi dan pasien dengan malaria serebral. Level serum TNF- $\alpha$ meningkat pada pasien malaria tanpa komplikasi tetapi tertinggi pada pasien dengan malaria cerebral. ${ }^{7}$

Penulis menyadari adanya banyak kekurangan dalam karya tulis ini, Beberapa keterbatasan dalam penelitian ini meliputi keterbatasan variabel penelitian , sampel penelitian, waktu dan data penelitian, serta dana penelitian.

\section{SIMPULAN}

TNF- $\alpha$ memegang peranan penting pada malaria. Pada kondisi tertentu TNF- $\alpha$ dapat melindungi, tetapi pada produksi yang berlebih TNF- $\alpha$ dapat merusak hospes dan berperan pada patologi penyakit. Gejala khas malaria terjadi saat eritrosit pecah sewaktu proses skizogoni,

toksin parasit menyebabkan sel hospes melepaskan sitokin, salah satunya TNF- $\alpha$. Pada penelitian ini didapatkan korelasi yang signifikan antara kadar TNF- $\alpha$ dengan densitas parasit.

\section{DAFTAR PUSTAKA}

1. Aru WS, Bambang S, Idrus A, Marcellus SK, Siti S,. Buku Ajar Ilmu Penyakit Dalam, Jilid III ed $5^{\text {th }}$.Jakarta 2009

2. Irawati L, Acang N, Irawati N. Ekspresi Tumor Necrosis Factor-ALFA dan Inter Leukin-10 pada Infeksi Malaria Falciparum.2008 Jun. vol 32

3. Ishartadiati K, PERANAN TNF, IL-1, DAN IL-6 PADA RESPON IMUN TERHADAP PROTOZOA. Surabaya. 2009

4. Harijanto PN, Nugroho A, Gunawan CA, Malaria: dari Molekuler ke Klinis. Edisi ke-2, Jakarta: Penerbit Buku Kedokteran EGC; 2012

5. Abbas AK, Lichtman AH. Cellular and Molecular Immunology. Edisi ke-5. China: Saunders Elsevier

6. Hemmer CJ, Holst FG, Kern P, Chiwakata CB, Dietrich M, Reisinger EC. Stronger host response per parasitized erythrocyte in Plasmodium vivax or ovale than in Plasmodium falciparum malariae.2006 Jun;11(6):817-23

7. Bhaskaran k, Ebonyi O, Walther B, Walther M, Predictors of hyperlactataemia among children presenting with malaria in a low transmission area in The Gambia. 2013 (diakses 10 Februari 2014). Available from:

http://www.malariajournal.com/content/12/ $1 / 423$ 
Jurnal e-Biomedik (eBM), Volume 2, Nomor 2, Juli 2014

8. Kakkilaya B.S, Pathogenesis of Malaria)

Available

from: [internet]. Dr. B.S. Kakkilaya's Malaria Web Site (diakses 10Februari2014).

http://www.malariasite.com/malaria/Evolut ion.htm 